\title{
Effect of the Ethanol Extract of Mimosa Leaves on the Blood Glucose, Malondialdehyde, and Histopathological Characteristics of Wistar Rats
}

\author{
S. Wahjuni ${ }^{1 *}$, I. A. Raka Astiti Asih ${ }^{1}$, Desmon Tutu Bili ${ }^{1}$, Ni Made Puspawati ${ }^{1}$, Ahmad Fudholi ${ }^{2,3}$ (D) \\ ${ }^{1}$ Program Studi Kimia, Fakultas Matematika dan IImu Pengetahuan Alam, Universitas Udayana, Jimbaran, Bali, Indonesia; \\ ${ }^{2}$ Solar Energy Research Institute, Universiti Kebangsaan Malaysia, Selangor, Malaysia; ${ }^{3}$ National Research and Innovation \\ Agency Republic of Indonesia (BRIN), Bandung, Indonesia
}

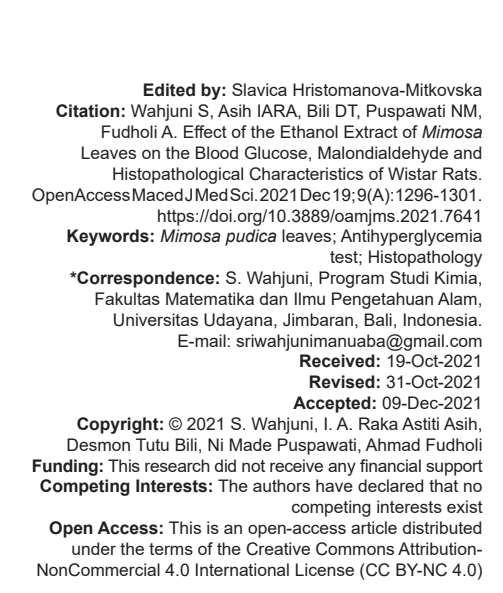

\begin{abstract}
BACKGROUND: Hyperglycemia, a condition characterized by high blood glucose levels, is one of the hallmarks of type 2 diabetes mellitus.

AIM: This study aimed to (1) determine if the ethanol extract of Mimosa leaves could lower blood glucose levels in Wistar rats with hyperglycemia and (2) identify the components of active compounds with antihyperglycemic properties.

METHODS: In the blood glucose level reduction test, Wistar rats were used as an animal model of diabetes induced by streptozotocin. Blood glucose levels were measured using a glucometer, and active compounds were identified through Liquid Chromatography with tandem mass spectrometry (LCMS/MS).

RESULTS: Results showed that the ethanol extract of Mimosa pudica leaves might significantly lower the blood glucose, and malondialdehyde levels of rats with hyperglycemia at $150 \mathrm{mg} / \mathrm{kg} \mathrm{BB}(p<0.05)$. LCMS/MS analysis revealed that the ethanol extract of Mimosa leaves likely contained seven compounds that could decrease blood glucose and malondialdehyde levels: DL-valine, indoline, 2-quinolinol, trans-anrthole, luteolin, apigenin, linoliamide, and luteolinin.

CONCLUSION: Histophatological determination with HE staining for pancreas.
\end{abstract}

\section{Introduction}

One of the characteristics of type 2 diabetes mellitus is an increase in blood glucose (hyperglycemia). Hyperglycemia is a condition characterized by a blood glucose level that is higher than normal because of the excessive production of free radicals and the stimulation of oxidative stress. Oxidative stress is due to the increased amount of glucose in the blood, causing glucose autooxidation, and forming reactive oxygen species (ROS). ROS then react with the acidic components of the cell membrane, resulting in a chain reaction known as lipid peroxidation. Lipid peroxidation causes the chain of fatty acids to break into various toxic compounds and damage the cell membrane. Consequently, it triggers hyperglycemia. An increase in ROS is one of the causes of high blood glucose levels. The intake of the ethanol extract of the daughter of shame antioxidant compounds can reduce blood glucose and malondialdehyde in hyperglycemic rats.

Antioxidants have an important role in the health of the human body because one of their functions is to inhibit the occurrence of oxidation reactions in the body. However, the body needs additional antioxidants or endogenous antioxidants when the amount of free radicals increases. Several sources of antioxidants can be found; for example, they can be obtained from plants that contain secondary metabolites that can serve as antihyperglycemic agents [1].

Herbal plants and their parts, such as Mimosa leaves, have been widely used to treat diabetes. For example, Mimosa pudica (L.), which is often found on the side of the road and has a distinct characteristic of closing leaves when touched, is known as a medicinal ingredient by many traditional communities. Its stems, roots, flowers, and leaves are the most commonly used parts in traditional medicine [2]. Mimosa leaves have several pharmacological activities, such as antidiabetes, antitoxicity, antihepatotoxicity, antioxidant properties, and wound healing [3]. Mimosa leaves are potential antihyperglycemic agents because they contain secondary metabolites, such as alkaloids, flavonoids, terpenoids, saponins, and coumarins, which act as antioxidants [4]. The ability of antioxidant compounds to lower blood glucose 
levels by preventing oxidation reactions, so damage to pancreatic cells can be prevented. In addition, secondary metabolites can synergistically minimize the complications of type 2 diabetes mellitus, which is characterized by reduced oxidative stress. Flavonoids can decrease glucose absorption and regulate the excretory activity of enzymes involved in carbohydrate metabolism.

This study was performed to examine the effect of the ethanol extract of Mimosa leaves on blood glucose and malondialdehyde levels of hyperglycemic Wistar rats induced by streptozotocin and identify the active compounds.

\section{Materials and Methods}

\section{Ingredients}

Mimosa leaves were taken from Jimbaran, Bali, Indonesia. They were determined at the LIPIUPT Plant Conservation Center of the Eka Karya Botanical Gardens, Bali. The following chemicals were used: $96 \%$ ethanol, distilled water, streptozotocin (Sigma Aldrich), Mg powder, hydrochloric acid, Wilsatter reagent, Meyer reagent, acetic anhydride, concentrated $\mathrm{H}_{2} \mathrm{SO}_{4}$, and buffer. Filter paper was also utilized. Male Wistar rats aged 2-3 months and weighing 150-200 $\mathrm{g}$ were the experimental animals examined in this study.

\section{Tools}

The following instruments were used in this study: beaker, measuring cup, spatula, blender, glass jar, dropper, filler, measuring flask, funnel, porcelain cup, analytical balance, aluminium foil, water bath, sonde tool, gloves, mask, desiccator, liquid chromatography with tandem mass spectrometry (LCMS/MS) Xevo type G2 TOF, rotary evaporator and Gluco M stick. MDA and histopathology kits were used for microscopy with $\times 100$ magnification microtechnical method.

\section{Ethanol extract of Mimosa leaves}

Mimosa leaves were cleaned with running water, cut into small pieces and air dried without exposure to sunlight. Afterward, the moisture content was determined (9.76\%). The Mimosa leaves were mashed in a blender to obtain their powder form. Then, $180 \mathrm{~g}$ of Mimosa leaf powder was macerated with $96 \%$ ethanol once for $24 \mathrm{~h}$. The maceration results were obtained. The solvent was evaporated with a rotary evaporator at $450^{\circ} \mathrm{C}$ to obtain a thick ethanol extract. This extract was used to examine the decrease in blood glucose levels and identify its compounds.

\section{Blood glucose level reduction test}

A real experimental method with a pre-test/post-test only control group design was performed [5]. Eighteen male Wistar rats aged \pm 3 months and weighing 150-200 g were alkylated for 1 week to acclimate in the environment. Then, they were divided into six groups according to treatment: $\mathrm{PO}=$ positive control; P1= negative control; P2 = ethanol extract of Mimosa leaves of $50 \mathrm{mg} / \mathrm{kg} \mathrm{BW}$; P3 = ethanol extract of Mimosa leaves of $100 \mathrm{mg} / \mathrm{kg} \mathrm{BW}$; P4 = ethanol extract of Mimosa leaves of $150 \mathrm{mg} / \mathrm{kg} \mathrm{BW}$; and $\mathrm{P} 5=$ glibenclamide dose of $0.18 \mathrm{mg} / \mathrm{kg}$ BW. The treatments were given for 14 days. All the treatment groups were induced with streptozotocin at a dose of $40 \mathrm{mg} / \mathrm{kg}$ BW. Blood glucose levels were measured with a glucometer on the $4^{\text {th }}$ day after streptozotocin induction and $17^{\text {th }}$ day after the treatment with various doses of the ethanol extract of Mimosa leaves by using the blood drawn from the tail vein of the rats [6]. The blood glucose levels were statistically analyzed through ANOVA in SPSS 2.3 for Windows. If the results were significant, a post hoc test follow-up via LSD was performed.

\section{Malondialdehyde test}

A real experimental method with a pre-test/ post-test only control group design was performed [5]. Eighteen male Wistar rats aged \pm 3 months and weighing 150-200 g were alkylated for 1 week to acclimate in the environment. Various doses of Mimosa leaves leaf extract were administered to the hyperglycemic Wistar rats through the thiobarbituric acid reactive substance (TBARS) method using a QuantiChrom TMT BARS assay kit (DTBA-100) in accordance with the manufacturer's protocol. Mean MDA levels were obtained.

\section{Identification of active compounds through phytochemical test and LCMS/MS}

The active compounds of the ethanol extract of Mimosa leaves were identified through phytochemical tests and LCMS/MS by comparing the spectrum of the analysis results with the spectrum of the standard compound in the database. A chromatogram was obtained and examined using MassLynx V4.1 to determine the mass spectrum.

\section{Results and Discussion}

\section{Mimosa leaf extract}

After the maceration of $180 \mathrm{~g}$ of powdered Mimosa leaves (M. pudica $L$ ) with ethanol solvent once 
for $24 \mathrm{~h}, 23.76 \mathrm{~g}$ of thick blackish green ethanol extract with a yield percentage of $12.97 \%$ was obtained. Ethanol was chosen as the solvent because it is polar, so all secondary metabolites can be attracted effectively.

\section{Decrease in blood glucose levels}

The blood glucose level profile of Wistar rats, particularly the blood glucose levels after streptozotocin induction on day 4 (pre-test) and after the administration of various doses of ethanol extract and glibenclamide on day 17 (post-test), is presented in Table 1 and Figure 1. All the groups of streptozotocin-induced rats had hyperglycemia with an average glucose level of 160-175 mg/dL. Gabriel et al. [7] indicated that test animals can considered hyperglycemic if they have blood glucose levels exceeding $140 \mathrm{mg} / \mathrm{dL}$. Streptozotocin is a diabetic agent that is selective for pancreatic beta cells. Streptozotocin induction causes a decrease in peripheral insulin receptor sensitivity; as such, it increases insulin resistance and causes an increase in blood glucose after a long-term use [8].

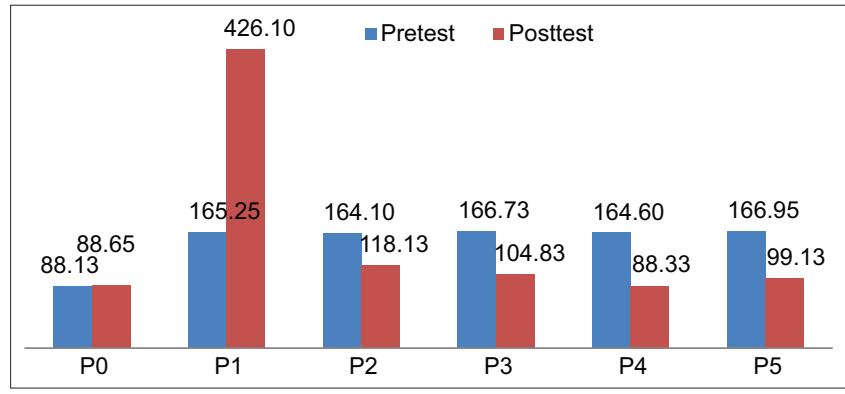

Figure 1: Decrease in blood glucose levels

On the $17^{\text {th }}$ day (post-test), the administration of the ethanol extract of Mimosa leaves at various doses decreased the blood glucose levels after 14 days of administration. The ethanol extract of Mimosa leaves with a dose of $150 \mathrm{mg} / \mathrm{kg} \mathrm{BW}$ a significant decrease.

Statistical analysis revealed that the data of blood glucose levels were normally distributed $(p>0.05)$ and homogeneous $(p>0.05)$. As such, oneway ANOVA was also conducted. One-way ANOVA showed a significance value of $p=0.000(p<0.05)$, which indicated that the blood glucose levels in the negative group (P1) significantly differed from those in the treatment groups (P2, P3, P4 and P5) after the administration of the ethanol extract of Mimosa leaves. A follow-up test involving a post hoc test with LSD was conducted to determine the effect between groups.

The P5 group significantly differed ( $p<0.05$ ) from the treatment groups (P1, P3 and P4). This result indicated that the P5 treatment group experienced a decrease in blood glucose levels because of glibenclamide, which is included in the antidiabetic drug class. The mechanism by which glibenclamide stimulates pancreatic cells to produce insulin involves the inhibition of ATP-sensitive $\mathrm{K}^{+}$channels in pancreatic
Table 1: LSD test results

\begin{tabular}{llll}
\hline Treatment group & $\mathrm{n}$ & $\begin{array}{l}\text { Average } \pm \mathrm{SD} \text { after induction } \\
\text { of Streptozotocin }(\mathrm{mg} / \mathrm{dL})\end{array}$ & $\begin{array}{l}\text { Rata-rata } \pm \mathrm{SD} \text { after giving of } \\
\text { test material }(\mathrm{mg} / \mathrm{dL})\end{array}$ \\
\hline P0 & 4 & $88.13 \pm 2.26$ & $88.65 \pm 2.5$ \\
P1 & 4 & $165.25 \pm 1.76$ & $426.10 \pm 4.7$ \\
P2 & 4 & $164.10 \pm 1.91$ & $118.13 \pm 1.7$ \\
P3 & 4 & $166.73 \pm 1.95$ & $104.83 \pm 1.7$ \\
P4 & 4 & $164.60 \pm 1.67$ & $89.33 \pm 1.4$ \\
P5 & 4 & $166.95 \pm 0.98$ & $99.13 \pm 2.1$ \\
\hline
\end{tabular}

cells. Consequently, the cell membrane depolarises, and $\mathrm{Ca}^{2+}$ channels open to allow $\mathrm{Ca}^{2+}$ to enter pancreatic cells.

Increasing the dose of the extract did not always result in a large decrease in blood glucose levels. In particular, increasing the dose of $150 \mathrm{mg} / \mathrm{kg} \mathrm{BW}$ did not increase the blood glucose and malondialdehyde levels. The rats' body could not accept this dose, so this extract was effective in lowering blood glucose and malondialdehyde levels.

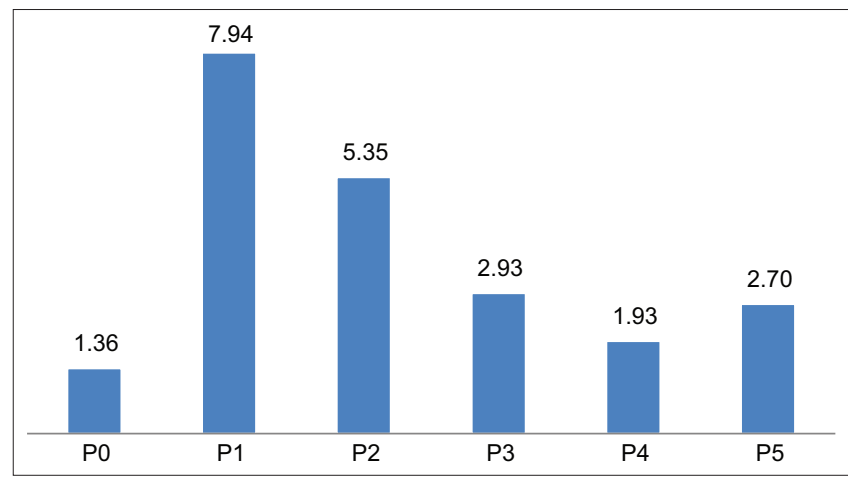

Figure 2: Decrease in malondialdehyde levels

Blood glucose levels decrease because of secondary metabolite compounds that act as antioxidants and work synergistically in the ethanol extract of Mimosa leaves. In a hyperglycemic state, it causes an increase in oxidative stress, that is, an increase in the production of free radicals in the body and a decrease in endogenous antioxidants (antioxidants produced in the body). The ability of antioxidant compounds to reduce blood glucose levels by preventing oxidation reactions; thus, damage to pancreatic cells can be prevented. Flavonoid compounds play a role in lowering blood glucose levels by inhibiting the activity of glucosidase; as such, glucose absorption in the small intestine can be reduced. In addition, these compounds participate in several mechanisms, including an increase in insulin resistance, the inhibition of the gluconeogenesis pathway and the release of insulin from beta cells [9], [10]. Mimosa leaves likely contain a quercetin-type flavonoid [11]. Quercetin possibly exhibits antioxidant properties, specifically the ability to decrease blood glucose levels through free radical scavenging mechanisms. Alkaloid compounds are also involved in the reduction of blood glucose levels and the regeneration of damaged pancreatic cells. Alkaloids work by increasing glucose transport in the blood, inhibiting glucose absorption in the intestine, 
stimulating glycogen synthesis, and inhibiting.

Glucose synthesis by inhibiting enzymes that play a role in gluconeogenesis (glucose-6- phosphatase and fructose-1,6-bisphosphatase). The inhibition of these two enzymes can reduce glucose formation from carbohydrates, which are the main source of glucose formation [12]. Polyphenol compounds can function as antioxidants by binding to free radicals to protect pancreatic cells from the toxic effects of free radicals produced during chronic hyperglycemia conditions; therefore, these compounds also decrease blood glucose levels [13].

\section{Decrease in malondialdehyde levels}

Figure 2 shows that the group of the rats that received the ethanol extract of Mimosa leaves at a dose of $50 \mathrm{mg} / \mathrm{kg}$ BW (P2) had an average MDA level of $5.35 \pm$ $0.51 \mathrm{M}$ or a decrease in MDA levels of $2.59 \mathrm{M}$ compared with that of the negative control group (P1). The P3 treatment group with a dose of $100 \mathrm{mg} / \mathrm{kg} \mathrm{BW}$ had an average MDA level of $2.93 \pm 0.50 \mathrm{M}$ or a decrease in MDA levels of $5.01 \mathrm{M}$ compared with that of the negative control group. The P4 treatment group with a dose of $150 \mathrm{mg} / \mathrm{kg}$ BW had an average MDA level of $1.93 \pm$ $0.36 \mathrm{M}$ or a decrease in MDA levels of $6.01 \mathrm{M}$ compared with that of the negative control group. The comparison of the decrease in MDA levels in rats revealed that the administration of the ethanol extract of Mimosa leaves at a dose of $150 \mathrm{mg} / \mathrm{kg} \mathrm{BW}$ elicited the highest degree of decreasing the MDA levels in the negative group.

The most remarkable decrease in the MDA levels was found in the treatment group (P4) at a dose of $150 \mathrm{mg} / \mathrm{kg} \mathrm{BW}$ with a decrease in MDA levels of 6.01 M compared with that of the negative control group.
Kurniasari [14] showed that the methanol extract of the roots of Mimosa leaves at a dose of $500 \mathrm{mg} / \mathrm{kg} \mathrm{BW}$ administered for 10 days can inhibit the streptozotocininduced increase in the MDA levels in the serum of Wistar rats (Rattus norvegicus) because the methanol extract of the roots of Mimosa leaves contains flavonoid compounds that are potent antioxidant chain breaking.

Wulan et al. [15] reported that the ethanol extract of Mimosa leaves with a concentration of $100 \mathrm{mg} / \mathrm{L}$ has a high antioxidant activity with a percentage yield of $88.38 \%$ because it contains antioxidants such as flavonoids, alkaloids, terpenoids, saponins, and coumarins.

\section{LCMS/MS results of the active compounds of Mimosa leaves leaf extract}

The sample of the ethanol extract of M. pudica leaves prepared through the SPE method with a methanol eluent was injected into the LCMS/MS instrument with a stationary phase/C18 column (octadecyl silane) of as much as $5 \mu \mathrm{L}$ using a micro syringe. The results were presented in the form of a chromatogram, which was then analyzed using MassLynx v4.1 to determine the mass of the compound obtained from each retention time. The structure and name of the compound were checked on the website www.chesmspider.com. One $\mathrm{H}$ atom was subtracted because it is separated by firing one proton $\left(\mathrm{H}^{+}\right)$during the separation in MS. The chromatogram data are shown in Figure 3.

LCMS/MS revealed a chromatogram with eight peaks in the retention time range of 1-11 min. These peaks were then identified by analyzing the mass spectrum. The results of the mass spectrum analysis of each peak were then compared with the mass spectrum

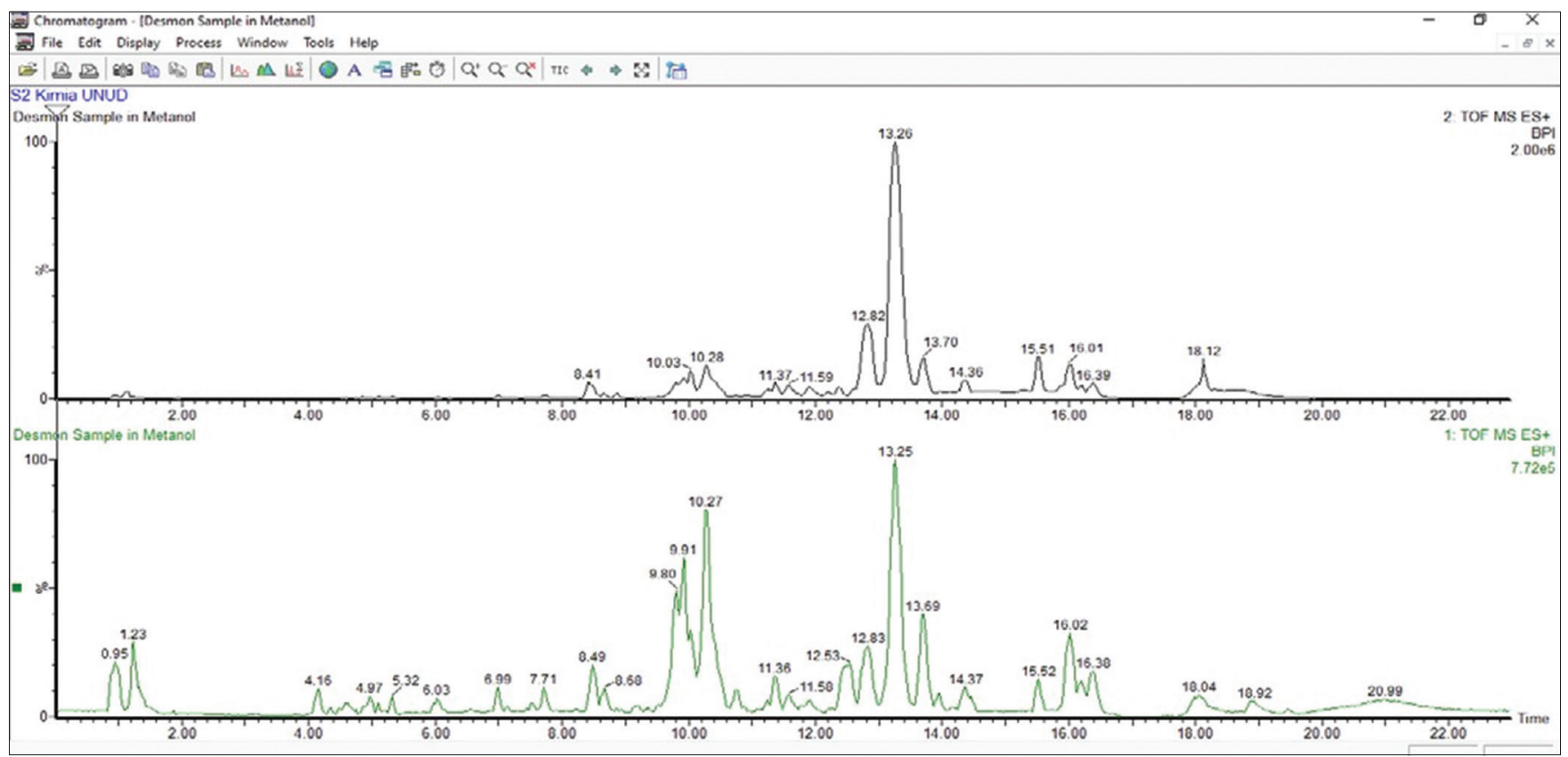

Figure 3: Chromatogram of liquid chromatography with tandem mass spectrometry ethanol extract of Mimosa leaves 
contained in the database to verify if the compounds were present in the ethanol extract of Mimosa leaves.

The compounds identified in the ethanol extract of Mimosa plants have the potential to reduce blood glucose levels (Table 2). These compounds were DL-valine, indoline, 2-methyl-1H-pyrrolo[2,3-f]quinolone, 2-quinolinol, trans-anethole, luteolin, apigenin, and linoliamide.

Table 2: Alleged compounds in the ethanol extract of Mimosa pudica L. leaves

\begin{tabular}{|c|c|c|c|c|}
\hline $\begin{array}{l}\text { Retention } \\
\text { time }\end{array}$ & $\begin{array}{l}\text { Ion } \mathrm{M}^{+} \\
(\mathrm{m} / \mathrm{z})\end{array}$ & $\begin{array}{l}\text { Chemical } \\
\text { formula }\end{array}$ & Alleged compound & Structure \\
\hline 1.232 & 118.0871 & $\mathrm{C}_{5} \mathrm{H}_{11} \mathrm{NO}_{2}$ & DL- Valine & \\
\hline 3.981 & 120.0810 & $\mathrm{C}_{8} \mathrm{H}_{9} \mathrm{~N}$ & $\begin{array}{l}\text { Indoline } \\
1 \mathrm{H} \text {-indole, 2,3- dihydro }\end{array}$ & \\
\hline 4.973 & 183.0918 & $\mathrm{C1}_{2} \mathrm{H}_{10} \mathrm{~N} 2$ & $\begin{array}{l}\text { 2-Methyl-1H-pyrrolo[2,3- } \\
\text { f] quinolone }\end{array}$ & \\
\hline 4.973 & 146.0601 & $\mathrm{C}_{9} \mathrm{H}_{7} \mathrm{NO}$ & 2-Quinolinol & \\
\hline 4.973 & 149.0690 & $\mathrm{C} 10 \mathrm{H} 12 \mathrm{O}$ & $\begin{array}{l}\text { trans-Anethole } \\
\text { (E)-1-(4-Methoxyphenyl) } \\
\text { prope ne }\end{array}$ & \\
\hline 7.714 & 287.0548 & $\mathrm{C} 15 \mathrm{H} 1006$ & $\begin{array}{l}\text { Luteolin2- } \\
\text { (3,4-Dihydroxyphenyl) } \\
\text { - 5,7-dihydroxy-4H- } \\
\text { chromen-4-one }\end{array}$ & \\
\hline 8.664 & 271.0609 & $\mathrm{C} 15 \mathrm{H} 1005$ & $\begin{array}{l}\text { Apigenin } \\
\text { 5,7-dihydroxy-2-(4- } \\
\text { hydroxyphenyl) } \\
-4 \mathrm{H} \text { - cromen-4-one }\end{array}$ & \\
\hline 10.020 & 280.2633 & $\mathrm{C} 18 \mathrm{H} 33 \mathrm{~N} O$ & $\begin{array}{l}\text { Linoliamide }(9 Z, 12 Z) \\
-9,12 \text {-octadecadiamid }\end{array}$ & \\
\hline
\end{tabular}

\section{Histopathological test results of pancreatic Hyperglycemia in Wistar rats}

Histopathological observations revealed that the pancreas of normal rats (Figure 4a) showed an orderly arrangement of cells that spread in the islets of Langerhans. The pancreas of the rats negatively treated with streptozotocin had an induced inflammation, as indicated by the large number of empty spaces in the middle of the islets of Langerhans (Figure $4 \mathrm{~b}$ ) in the form of islets of Langerhans. started to break down. The administration of the ethanol extract of Mimosa leaves at $50 \mathrm{mg} / \mathrm{kg} \mathrm{BW}$ with streptozotocin induction was still damaged (Figure 4c). The administration of the ethanol extract of $100 \mathrm{mg} / \mathrm{kgBW}$ induced by streptozotocin showed that the islets of Langerhans had irregularly arranged cells (necrosis; Figure 4d). At $150 \mathrm{~g} / \mathrm{kg}$ BW Mimosa leaves induced by streptozotocin, the arrangement of the cells that spread in the islets of Langerhans was regular, thus approaching normal pancreatic tissue conditions (Figure 4e). The Wistar rats treated with streptozotocin and $0.18 \mathrm{mg} / \mathrm{kg}$ BW glibenclamine still showed an irregular arrangement of Langerhans cells (Figure 4f). Hematoxylin-eosin staining revealed that the cells in the islets of Langerhans could not differentiate, so it was only focused on pancreatic cells.

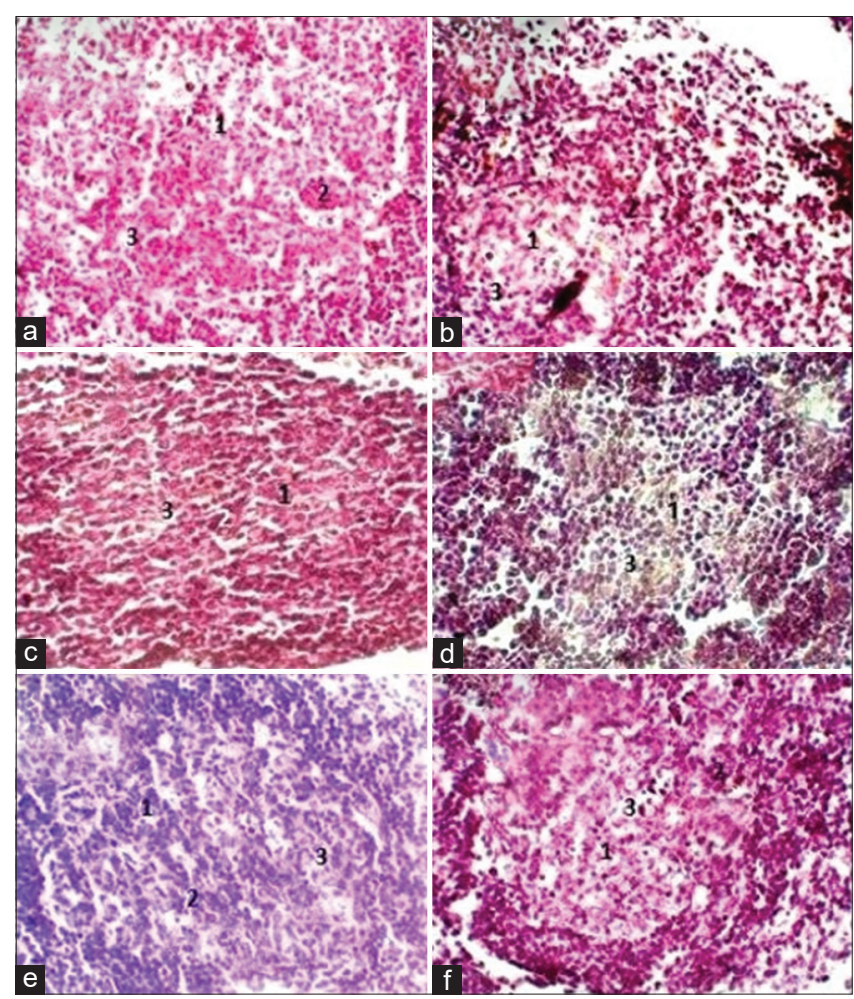

Figure 4: (a-f) Histopathological observations of the rat pancreas

\section{Conclusion}

The ethanol extract of Mimosa leaves at doses of 50,100 and $150 \mathrm{mg} / \mathrm{kg} \mathrm{BW}$ could reduce the blood glucose and malondialdehyde levels of hyperglycemic Wistar rats. At a dose of $150 \mathrm{mg} / \mathrm{kg} \mathrm{BW}$, the blood glucose and malondialdehyde levels significantly decreased $(p<0.05)$. This extract was likely composed of seven active compounds containing flavonoids that could lower blood glucose and malondialdehyde levels. The histopathological image of the pancreas of the hyperglycemic Wistar rats administered with $150 \mathrm{mg} / \mathrm{kg}$ BW showed changes in Langerhans cells close to normal pancreatic tissue conditions (1-E). 


\section{References}

1. Erguder BI, Avci A, Devrim E, Durak I. Effects of cooking techniques on antioxidant enzyme activities of some fruits and vegetables. Turk J Med Sci. 2007;37(3):151-6.

2. Banik G, Bawari M, Dutta CM, Choudhury S, Sharma GD. Some antidiabetic plants of Southern Assam, India. J Sci Technol. 2010;5:114-9.

3. Azmi L, Singh MK, Akhtar AK. Pharmacological and biological overview on Mimosa pudica Linn. Int J Pharm Life Sci. 2011;2(11):1226-34.

4. Tamilarasi T, Ananthi T. Phytochemical analysis and anti microbial activity of Mimosa pudica Linn. Res J Chem Sci. 2012;2(2):72-4.

5. Pocock SJ. Clinical Trial a Practical Aproach. New York: A Willey Medical Publication; 2008.

6. Srinivasan K, Ramarao P. Animal models in type 2 diabetes research: An overview. Indian J Med Res. 2007;125:451-472. PMid: 17496368

7. Gabriel El, Uneojo OV, Chukwudi E. Evaluation of methanol extract of Gongronema latifolium leaves singly and in combination with glibenclamide for anti-hyperglycemic effects in alloxan-induced hyperglycemic rats. J Intercult Ethnopharmacol. 2014;3(3):119-22. https://doi.org/10.5455/jice.20140610054950 PMid:26401359

8. Malik B. Pengaruh Frekuensi Pemberian Jus Sargassum Sp. Terhadap Penurunan Kadar Glukosa Darah Dan Peningkatan Tnf- $\alpha$ Pada Mata Dan Otak Tikus Diabetes Mellitus Tipe 2. Doctoral Dissertation. Malang, Indonesia: Universitas Brawijaya;

\section{8.}

9. Ghorbani A, Rashidi R, Shafiee-Nick R. Flavonoids for preserving pancreatic beta cell survival and function: A mechanistic review. Biomed Pharmacother. 2019;111:947-57. https://doi. org/10.1016/j.biopha.2018.12.127 PMid:30841474

10. Karim F, Susilawati S, Oswari LD, Fadiya F, Nadya N. Uji aktivitas penghambatan Enzim-glucosidase ekstrak air dan ekstrak etanol kayu kuning (Arcangelisia flava). J Kedokteran dan Kesehatan. 2021;8(1):53-60.

11. Mustapa K, Rizky A, Jura MR. Pengaruh ekstrak tanaman putri malu (Mimosa pudica Linn) terhadap penurunan kadar glukosa darah pada mencit (Mus musculus). J Akademika Kimia. 2017;6(1):7-14.

12. Rosmiati M, Nurjanah KA, Suantika G, Putra RE. Application of compost produced by bioconversion of coffee husk by black soldier fly larvae (Hermetia illucens) as solid fertilizer to lettuce (Lactuca sativa var. crispa): Impact to growth. Proc Int Conf Green Technol. 2017;8(1):38-44.

13. Prameswari OM, Widjanarko SB. Uji efek ekstrak air daun pandan wangi terhadap penurunan kadar glukosa darah dan histopatologi tikus diabetes mellitus. J Pangan dan Agroindustri. 2013;2(2):16-27.

14. Kurniasari FT. Pengaruh Ekstrak Metanol Akar Putri Malu (Mimosa pudica L) Pada Kadar Malondialdehidea (MDA) Serum Tikus Wistar (Rattus Norvegicus) Jantan Diabetik Induksi Streptozotocin. Indonesia: Universitas Brawijaya; 2013

15. Wulan W, Yudistira A, Rotinsulu H. Uji aktivitas antioksidan dari ekstrak etanol daun Mimosa pudica Linn. menggunakan metode DPPH. Pharmacon. 2019;8(1):106-13. 